\title{
Corporate Social Responsibility and Stakeholders' Management of Export Companies in Foreign Markets
}

\author{
Andrija Barić \\ KONČAR - Power Plant and Electric Traction Engineering Inc., Croatia \\ Mislav Ante Omazić \\ University of Zagreb, Faculty of Economics and Business, Croatia \\ Ana Aleksić \\ University of Zagreb, Faculty of Economics and Business, Croatia
}

\section{Abstract}

In this paper, we investigate how corporate social responsibility (hereafter CSR) practices of domestic Croatian mid and large size firms differentiate them on foreign markets. Still, in order for export organizations to realize benefits offered by CSR, export organizations need to identify their main stakeholder groups and interests, and adequately design their CSR activities. This paper provides an overview of the main CSR activities of export organizations in foreign markets and analyses their stakeholder's management as well as the quality of relationships with their primary and secondary stakeholders on foreign markets. Results of empirical research on a sample of 78 medium and large Croatian export companies show that these export organizations invest significant efforts in implementation of different CSR activities, and into relationships with their primary stakeholders.

Keywords: corporate social responsibility, CSR, stakeholders, export, foreign markets, globalization

JEL classification: F23, M14

\section{Introduction}

Corporate social responsibility (hereafter CSR) emphasizes the additional and specific role of organizations in their societies, stressing their utility and purpose beyond the primary function of selling goods or providing services to customers (Wang et al., 2016). The concept itself, as well as its activities, have become an integral part of organizational strategy, and implementation of CSR in the strategic organizational process becomes a prerequisite for long term sustainability (Bonn and Fisher, 2011). Many business organizations have recognised that their conduct in value chain management may have significant reputational and performance effects (Castka \& Balzarova, 2008; Kaufman, 2006).

Complex nature of globalization, on the other side, as well as process related to globalization, have significantly changed the nature of business (Reese et al., 2019). By generating a world connected by markets (Makarova et al., 2019) globalization has pushed organizations to erase national borders and search for profit on a global market. Trying to position and distinguish themselves among competitors on a global market, for organizations, CSR has been recognized as an important differentiation strategy (Boehe and Cruz, 2010). Not only that it contributes to the transfer of brand image and reputation to customers in export markets (Hossain et al., 2013), but as Godos-Díez et al. (2018) emphasize for companies operating in culturally different 
environment, CSR helps them to adapt to new environments, earn legitimacy and reinforce competitive advantage on the international stage.

As such, CSR is no longer considered a luxury, but an imperative that allows longterm and stable support, and positive corporate reputation for internal and external stakeholders on different markets. Collaboration, not only between different stakeholders and business organization but throughout entire value chains is seen as basis for sustainable business models (Horvath, 2001). Organizations do move from black-box entities to glass-box networks where transparency and trust among different dots are crucial. In that sense, organizations that ignore the social and ecological aspects of their own business within a global network can be short-term successful, but in the long term, they endanger business and survival on global and national markets (Jamali and Mirshak, 2007).

For achieving long term success on foreign markets, it is crucial for organizations to identify interests of their key stakeholders, and to recognize and design the most effective CSR activities that can help to satisfy their needs (Scherer and Palazzo, 2008). In the end, identified and satisfied stakeholders' interests, and good relationships with stakeholders create a positive company reputation, that eventually directly influences export activities and overall business performance of export companies (Scherer and Palazzo, 2008). As of the importance attributed to CSR activities and stakeholder's management, this paper presents the analysis of characteristics and specifics of export companies CSR activities and stakeholders management in foreign markets. Paper presents the results of empirical research done on a sample of 78 medium and large export companies from Croatia.

The goal of the paper is to analyse and present CSR activities and stakeholder's management of export companies on foreign markets in order to understand additionally the specifics of CSR on foreign markets, a subject often neglected in the current literature (lyer and Levis, 2019).

\section{CSR activities and stakeholder management in export organizations}

In a modern globalized and technologically interconnected world, it is very difficult to lead a successful business which focuses entirely on a domestic market and relations with internal and external stakeholders on a domestic market (Lee et al., 2015). When a firm enters export markets, its stakeholder composition changes, making it likely that trade will impact on CSR through this mechanism (Newman et al, 2018). Therefore, more companies over the world are continually developing strategic tools which would allow them to attain and keep a competitive advantage on an international market, and the CSR concept in business is becoming an increasingly important differentiation tool (Boulouta and Pitelis, 2014).

One of the reasons for the increase in popularity of the aforementioned concept is the fact that society as we know it is facing increasingly greater possibilities to be irrevocably damaged, which is why companies and their stakeholders are trying, in a mutually beneficial way, to protect and improve society as a whole, but also their own positions on the global market (Godos-Díez et al., 2018). In that context, a strategic approach to stakeholders through the CSR concept becomes a key tool for differentiation and building a positive reputation on international markets, in which the company has just started obtaining a market share and gaining a competitive advantage (Oh et al., 2017).

Hockerts (2015) points out four key methods that lead to creating competitive advantage through CSR in business: (i) increasing the efficiency of business processes 
and communication with stakeholders; (ii) creating a positive social image of the organization; (iii) lowering the risk of potential damages in business operations, and (iv) creating new types of buyers and markets. Since every for-profit organization uses specific tools for building adequate relationships with internal and external stakeholders, the competition is having a difficult time imitating successful companies and neutralizing a competitive advantage gained by having higher-quality relationships with stakeholders in international markets (Hillman and Keim, 2001). Besides, in order for managerial tools used in CSR to be effective, it is necessary to identify key stakeholders in international markets and apply an active approach and two-way communication. This is never an easy task because even individuals from the same group of stakeholders often have different values, motives, and even different competency levels (Ingenbleek et al., 2007).

Such a proactive approach towards internal and external stakeholders, along with creating and conducting a multi-layered communication strategy, can generate certain short-term financial costs because of the complexity of conducting and communicating CSR in multiple markets at the same time, but, in the long term, it opens the possibility for increasing the profitability of business operations by strengthening the positions on the international market (Garcia-Castro et al., 2009).

And in order for such an investment to be truly profitable for the management in the long term, a communication strategy that defines key communication channels is a key segment of CSR strategy, because it can greatly diminish tensions and conflicts between stakeholders, and open a channel of joint interests for the well-being of the community and company (Corus and Ozanne, 2012). In the past ten years, with the advent of social media, communication of for-profit and non-profit organizations with their own stakeholders has changed drastically, and an additional channel for a direct dialogue throughout the entire global market has been opened (Castello et al., 2013.) Social media is probably the most powerful tool export companies possess to inform and even educate stakeholders about socially responsible activities, as well as get feedback from them (Besiou et al., 2013).

The importance of dialogue with stakeholders throughout the global market is particularly important about very sensitive problems within communities. Stakeholders can quickly be informed about the complexity of the problem itself, and actively get involved in the decision making the process of conducting socially responsible activities, which consequentially leads to a positive reputation on the international market as well as a strengthening of market position through exports (Seele and Lock, 2015).

\section{Methodology}

\section{Research instrument and procedure}

In order to assess CSR activities and specifics of stakeholders' management of export companies on foreign markets, empirical research was designed and conducted. Research was done by using a survey method on a sample of 78 medium and large export companies from Croatia. These are companies whose income from export activities of goods and services was at a minimum of $25 \%$ of total revenue and their data were retrieved from the Croatian Exporters Association.

From the analysis of CSR activities in foreign markets, we followed seven dimensions of CSR defined by ISO 26000: environment, human right, labour practices, organization governance, fair operation practices, consumer issues problems and contribution to the community and society (ISO, 2010). We asked respondents to assess the level of implementation of a certain CSR activity by using Likert type scale from 1 to 5 (1 - not being implemented at all, 5 - continuously implemented). 
Stakeholders' management was assessed through a relationship with stakeholders. Each respondent was asked to identify the most important stakeholder groups for their organization and evaluate the quality of relationship with each group of stakeholders by using Likert type scale from 1 to 5 ( 1 - no quality at all, 5 - high quality). Following Wheeler and Sillanpaa (1997) primary external stakeholders analysed included consumers, suppliers, and the local community, while secondary were regulatory and legislative bodies, civil institutions, non-governmental organizations, media, and competing organizations.

\section{Sample characteristics}

A mentioned, our sample included 78 medium and large export companies from Croatia, who had a minimum of $25 \%$ of total revenue from export activities. As regards to their size, they were mostly large organizations, with more than 250 employees (51.3\%). Most of them come from the manufacturing industry $(48.7 \%)$, followed by wholesale and retail trade as well as repair of motor vehicles and motorcycles (14.1\%) and other service activities (10.3\%). One-quarter of sampled companies are subsidiaries of the multinational company, while rest are independent organizations, mostly with private ownership (59\%). Most of the sampled organizations as regard to their business activities are oriented on business with other companies (B2B) $(75.6 \%)$, while others do business to customers (B2C). For most of the organizations (32.1\%). export has $81-100 \%$ share in total revenue, they mostly (46.2\%) export to the European Union market by directly placing their products or service on the market (91.03\%).

\section{Results}

As regard to CSR activities results indicate sampled export organizations engage in a number of CSR activities on foreign markets. Table 1 presents descriptive statistics regarding seven dimensions of CSR activities in foreign markets as defined by ISO 26000.

Table 1

CSR Activities of Export Organizations in Foreign Markets

\begin{tabular}{llll}
\hline Variable & Variable description & Average & St. Dev. \\
\hline GOVERNANCE & organization governance & 3.95 & 1.068 \\
HUMAN_RIGHT & human right & 4.54 & .733 \\
LABOUR_PRACTICE & labour practices & 4.60 & .631 \\
ENVIRONMENT & environment & 4.51 & .698 \\
OPERATION PRACTICE & fair operation practices & 4.22 & .832 \\
CONSUMER & consumer issues problems & 4.28 & .788 \\
COMMUNITY_SOCIETYY & contribution to the community and & 3.92 & .894 \\
& society & 4.29 & .806 \\
\hline CSR_ACTIVITIES & sum of all CSR activities & \\
\hline
\end{tabular}

Note: $N=78,1$ - not being implemented at all, 5 - continuously implemented

Source: Authors' work

As it can be seen from the table above, as well as figure 1., the export organizations on foreign markets, state to have implemented higher levels of different CSR activities ( $\bar{x}=4.259$ for the sum of all CSR activities). For all but two activities respondents give high grades (above 4) for the level of their implementation. Mostly implemented are activities regarding labour practices $(\bar{x}=4.60)$, human right $(\bar{x}=4.54)$ and environment $(x=4.51)$, which is not surprising as most of these activities are legally defined and organizations need to implement and secure them in order to earn their legitimacy on 
the foreign market. Figure 1 presents the average values of the CSR activities among sampled organizations.

Figure 1

Average Values of Items Indicating CSR Activities

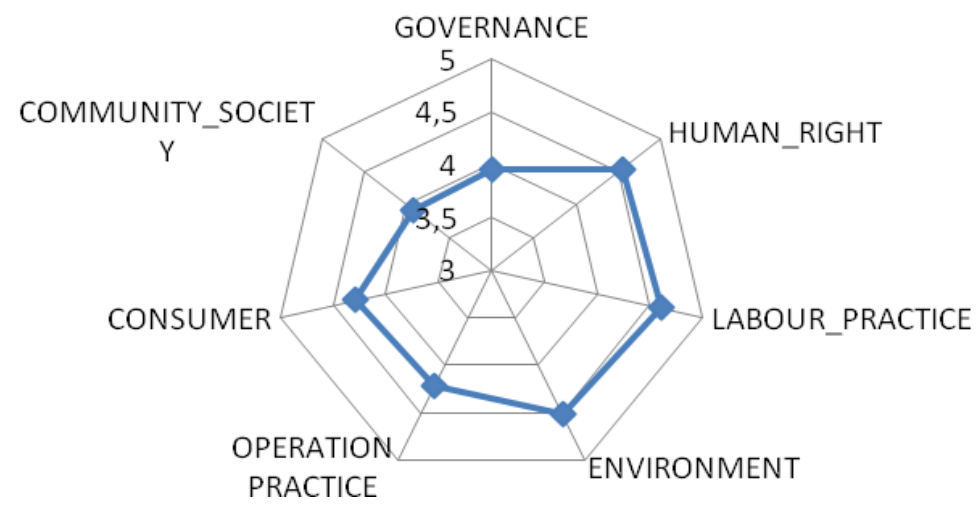

$\longrightarrow$ Average

Source: Authors' illustration

The least implemented activities are the ones related to contribution to the community and society $(\bar{x}=3.92)$. When it comes to stakeholders on foreign markets, export organization value differently quality of relation with distinct groups of stakeholders. Table 2 as well as figure 2 present assessment of the quality of relationship with different groups of stakeholders.

Table 2

Quality of Relationship with Different Groups of Stakeholders

\begin{tabular}{|c|c|c|c|}
\hline Variable & Variable description & Average & $\begin{array}{l}\text { St. } \\
\text { Dev. }\end{array}$ \\
\hline CONSUMERS & consumers as primary stakeholders & 4.21 & .745 \\
\hline SUPPLIERS & suppliers as primary stakeholders & 4.09 & .724 \\
\hline LOCAL_COMMUNITY & local community as primary stakeholders & 3.58 & .947 \\
\hline REGULAT_LEGISLATIVE & $\begin{array}{l}\text { regulatory and legislative bodies as } \\
\text { secondary stakeholders }\end{array}$ & 3.95 & .804 \\
\hline CIVIL_INSTITUTION & civil institutions as secondary stakeholders & 2.88 & 1.248 \\
\hline MEDIA & media & 3.19 & 1.217 \\
\hline NON_GOV_ORG & $\begin{array}{l}\text { non-governmental organizations as } \\
\text { secondary stakeholders }\end{array}$ & 2.71 & 1.387 \\
\hline COMPETING_ORG & $\begin{array}{l}\text { competing organizations as secondary } \\
\text { stakeholders }\end{array}$ & 2.96 & 1.062 \\
\hline TOTAL_QUALITY & $\begin{array}{l}\text { Overall quality of relation with } \\
\text { stakeholders }\end{array}$ & 3.45 & 1.016 \\
\hline
\end{tabular}

Note: $\mathrm{N}=78,1-$ no quality at all, 5 - high quality

Source: Authors' work

As expected, relationship with primary stakeholders is considered to be the most quality one, with relation towards consumers showing the highest average grade for quality $(\bar{x}=4.21)$ followed by relation towards suppliers $(\bar{x}=4,09)$. Primary stakeholders are vital for organizational continuance, thus as in their home markets, export organizations on foreign markets engage in more quality relations with them. Among secondary stakeholders the most quality assessed is the relation with regulatory and legislative bodies which is also not surprising if we consider them as the ones defining 
legal frameworks and guidance for behaviour on foreign markets. Figure 2 presents average values for quality of relation with stakeholders' groups among sampled organizations. Relationship with other secondary stakeholder is considered to be of less quality with relationship to non-governmental organizations considered to be of least quality $(\bar{x}=2.71)$.

Figure 2

Quality of Relationship with Stakeholders' Groups

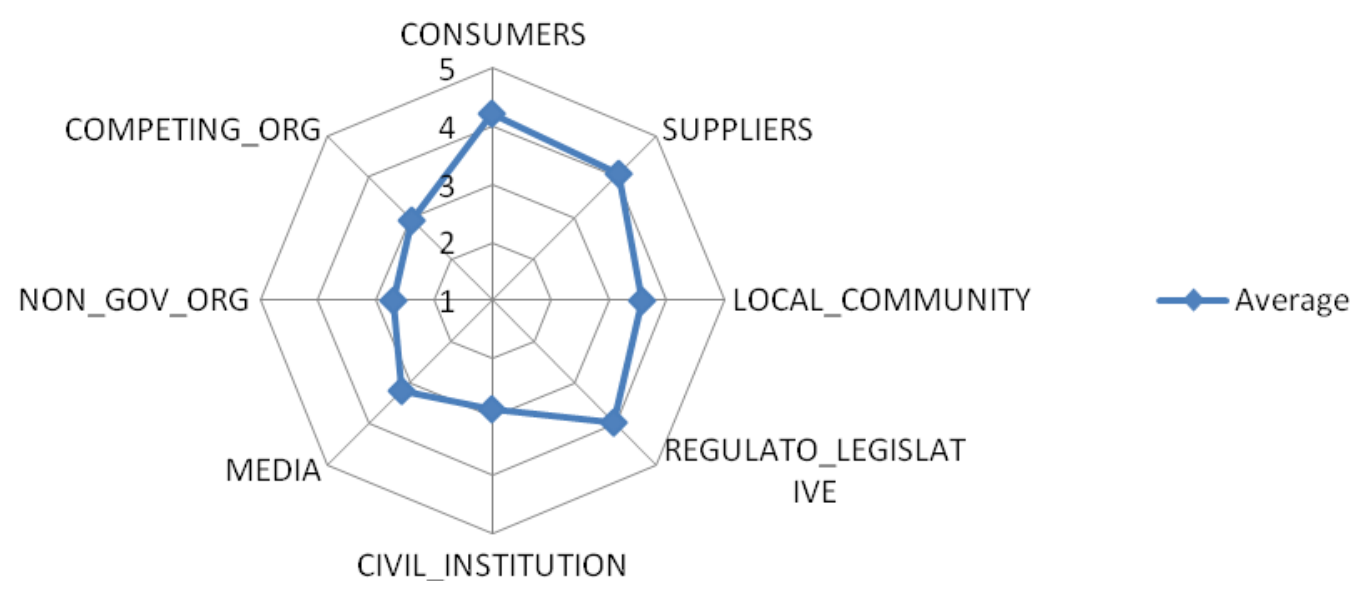

Source: Authors' illustration

\section{Conclusion}

In today's dynamic and interconnected international market, the management's exclusive focus on the local market as well as previously identified stakeholders in a local setting leads to isolation, and consequently an uncertain future (Sjöholm, 2003). Every day, every type of organization in the global market is surrounded by and act under the influence of various groups of internal and external stakeholders who have different motives and interests. They expect that organizations do business according to their attitudes, meanwhile continually increasing the value of the company (Raithel and Schwaiger, 2015). Because of the extreme complexity of conducting and communicating CSR activities, some organizations on the international market profit from CSR and obtain a competitive advantage, while some organizations, regardless of the amount of their investment, can't manage to obtain a return on investment nor a more positive reputation (Story and Neves, 2014). Therefore, management of modern export companies has to be skilled enough to: (i) identify key stakeholders on export markets; (ii) choose the right tools for conducting socially responsible activities; (iii) choose communication channels and methods for establishing dialogue and (iv) obtain a competitive advantage through differentiation based on the concept of CSR (Boehe and Cruz, 2010). Results of our research among medium and large export companies from Croatia shows they have realized the importance of CSR, and have implemented many CSR activities, oriented to different stakeholders' groups. Among them, quality of relationships with consumers and suppliers, as primary stakeholders, is considered the most quality one.

\section{References}

1. Besiou, M., Hunter, M. L., Van Wassenhove, L. N. (2013), "A web of watchdogs: stakeholder media networks and agenda-setting in response to corporate initiatives", Journal of Business Ethics, Vol. 118, No. 4, pp. 709-729. 
2. Boehe, D. M., Cruz, L. B. (2010), "Corporate social responsibility, product differentiation strategy and export performance", Journal of Business Ethics, Vol. 91, No. 2, pp. 325-346.

3. Bonn, I., Fisher, J. (2011), "Sustainability: the missing ingredient in strategy", Journal of Business Strategy, Vol. 32, No. 1, pp. 5-14.

4. Boulouta, I., Pitelis, C. N. (2014), "Who needs CSR? The impact of corporate social responsibility on national competitiveness", Journal of Business Ethics, Vol. 119, No. 3 , pp. 349-364.

5. Castello, I., Morsing, M., Schultz, F. (2013), "Communicative dynamics and the polyphony of corporate social responsibility in the network society", Journal of Business Ethics, Vol. 118, No. 4, pp. 683-694.

6. Castka, P., Balzarova, M. A. (2008), "ISO 26000 and supply chains-on the diffusion of the social responsibility standard", International Journal of Production Econonomics, Vol. 111, No. 2, pp. 274-286.

7. Corus, C., Ozanne, J. L. (2012), "Stakeholder engagement: Building participatory and deliberative spaces in subsistence markets", Journal of Business Research, Vol. 65, No. 12, pp. 1728-1735.

8. Garcia-Castro, R., Ariño, M. A., Canela, M. A. (2009), "Does social performance really lead to financial performance? Accounting for endogeneity", Journal of Business Ethics, Vol. 92, No. 1, pp. 107-126.

9. Godos-Díez, J.-L., Cabeza-García, L., Fernández-González, C. (2018), "Relationship between corporate social responsibility (CSR) and internationalisation strategies: a descriptive study in the Spanish context", Administrative Sciences, Vol. 8, No. 57.

10. Hillman, A. J., Keim, G. D. (2001), "Shareholder value, stakeholder management, and social issues: what's the bottom line", Strategic Management Journal, Vol. 22, No. 2, pp. 125-139.

11. Hockerts, K. (2015), "A cognitive perspective on the business case for corporate sustainability: a cognitive perspective of the business case", Business Strategy and the Environment, Vol. 24, No. 2, pp. 102-122.

12. Horvath, L. (2001) "Collaboration: the key to value creation in supply chain management", Supply Chain Management, Vol. 6, No. 5, pp. 205-207.

13. Hossain, T. B., Siwar, C., Jani, M. F. M., Bhuiyan, A. B. (2013), "Corporate social responsibility (CSR) for global market access: a Malaysian case study on small and medium enterprises (SMEs)", Research Journal of Applied Sciences, Engineering and Technology, Vol. 5, No. 1, pp. 60-65.

14. Ingenbleek, P., Binnekamp, M., Goddijn, S. (2007) "Setting standards for CSR: A comparative case study on criteria-formulating organizations", Journal of Business Research, Vol. 60, No. 5, pp. 539-548.

15. ISO (2010), Guidance on Social Responsibility, International Standard, ISO/FDIS 26000 , ISO copyright office, Geneva.

16. Iyer, G. R., Jarvis, L. (2019), "CSR adoption in the multinational hospitality context: A review of representative research and avenues for future research", International Journal of Contemporary Hospitality Management, Vol. 31, No. 10.

17. Jamali, D., Mirshak, R. (2007), "Corporate social responsibility: theory and practice in a developing country context", Journal of Business Ethics, Vol. 72, No. 3, pp. 243-262.

18. Kaufman, A. H. (2006), "WEV: A New Approach to Supply Chain Management", in Jonker, J., de Witte, M. (Eds.), Management Models for Corporate Social Responsibility, Springer, Berlin, pp. 75-81.

19. Lee, M., Yin, X., Lee, S., Weng, D. H., Peng, M. (2015), "The impact of home country institutions on new venture export: examining new ventures in transition economies", International Entrepreneurship and Management Journal, Vol. 11, No. 4, pp. 823-848.

20. Makarova, E. A., Makarova, E. L., Korsakova, T. V. (2019), "The role of globalization and integration in interdisciplinary research, culture and education development", Journal of History Culture and Art Research, Vol. 8, No. 1, pp. 111-127.

21. Newman, C., Rand, J., Trap, F., Trifkovic, N. (2018), "The transmission of socially responsible behaviour through international trade", European Economic Review, Vol. 101 , pp. 250-267. 
22. Oh, S., Hong, A., Hwang, J. (2017), "An analysis of CSR on firm financial performance in stakeholder perspectives", Sustainability, Vol. 9, No. 6.

23. Raithel, S., Schwaiger, M. (2015), "The effects of corporate reputation perceptions of the general public on shareholder value", Strategic Management Journal, Vol. 36, No. 6. pp. 945-956.

24. Reese, G., Rosenmann, A., Cameron, J. E. (2019), The Psychology of Globalization: Identity, Ideology, and Action, Academic Press, London.

25. Scherer, A. G., Palazzo, G. (2008), "Globalization and Corporate Social Responsibility", in Crane, A., McWilliams, A., Moon, J., Siegel, D. S. (Eds.), The Oxford Handbook of Corporate Social Responsibility, Oxford University Press, New York, pp. 413-431.

26. Seele, P., Lock, I. (2015), "Instrumental and/or deliberative? A typology of CSR communication tools", Journal of Business Ethics, Vol. 131, No. 2, pp. 401-414.

27. Sjöholm, F. (2003), "Which Indonesian firms export? The importance of foreign networks", Papers in Regional Science, Vol. 82, No. 3, pp. 333-350.

28. Story, J., Neves, P. (2015), "When corporate social responsibility (CSR) increases performance: exploring the role of intrinsic and extrinsic CSR attribution", Business Ethics: A European Review, Vol. 24, No. 2, pp. 111-124.

29. Wang, H., Tong, L., Takeuchi, R., George, G. (2016), "Corporate social responsibility: an overview and new research directions", Academy of Management Journal, Vol. 59, No. 2, pp. 534-544.

30. Wheeler, D., Sillanpaa, M. (1997), The stakeholder corporation, Pitman, London.

\section{About the authors}

Andrija Baric graduated from the Faculty of Economics and Business in Zagreb, Republic of Croatia, with a master degree in finance. He received a Ph.D. in Management at the same university with the dissertation thesis „Relationship between corporate social responsibility and export activities of medium-sized and large Croatian companies". Currently, he works in KONČAR - Power Plant and Electric Traction Engineering Inc. as CFO. His main research is corporate social responsibility in the export process. The author can be contacted at andrija.baric@koncar-ket.hr.

Mislav Ante Omazić started to work at the Faculty of Economics and Business Zagreb as a Teaching Assistant at the Department of Organization and Management. Today he is Associate Professor of the same institution where he teaches a variety of classes such as Corporate Social Responsibility, Business Ethics, Management, Project Management, and Change Management. He worked on various domestic and international projects for public, private and civil society organizations. During his research work, professor Omazić has published dozens of papers in professional and scientific journals home and abroad and is the author and editor of several books. The author can be contacted at momazic@efzg.hr.

Ana Aleksić, Ph.D. is an Assistant Professor at the Faculty of Economics and Business, University of Zagreb, Department of Organization and Management. Her research interests include various aspects of organizational behaviour, with a special emphasis on deviant workplace behaviour, and organizational design. She is the author and co-author of several book chapters and journal publications and actively participates as a consultant in a number of scientific and commercial projects. The author can be contacted at aaleksic@efzg.hr. 